\title{
Fire as Unruly Kin: Curriculum Silences and Human Responses
}

\author{
Annette Gough, Briony Towers, and Blanche Verlie
}

\section{INTRODUCTION}

When we started to write this chapter, large areas of Australia were on fire, including close to where we all live. The fire season in Australia in 2019 started earlier than previously, and continued into March 2020, a period that is now called the Black Summer. These fires have changed the way many Australians think of fire, their relationship with it, and the nature of society (Cave, 2020; Keneally, 2020; Marshall, 2020), and with climate change (Lippman et al., 2020; Flanagan, 2020; Marshall, 2020). The fires have opened up discussions about the relevance of traditional Indigenous burning practices to land management practices (Faa, 2019; Scolaro, 2018; Williamson et al., 2020) and strategies for reducing fire risk (Bonyhady, 2020). The fires have also opened up questions around bushfire education in schools, including bushfire prevention, mitigation, preparedness, and response in an Australian context (Towers et al., 2020).

The bushfires have impacted communities and their schools across most Australian states. Some schools were destroyed in the bushfires, with the New South Wales (NSW) government having 178 schools being bushfire affected (Chrysanthos, 2020). Even where the schools were saved, communities were affected. For example, in the small coastal town of Milton (NSW), a teacher at

A. Gough $(\bowtie) \cdot$ B. Towers

RMIT University, Melbourne, VIC, Australia

e-mail: annette.gough@rmit.edu.au

B. Verlie

The University of Sydney, Sydney, NSW, Australia

e-mail: blanche.verlie@sydney.edu.au

(C) The Author(s) 2022

M. F.G. Wallace et al. (eds.), Reimagining Science Education

in the Anthropocene, Palgrave Studies in Education and the Environment, https://doi.org/10.1007/978-3-030-79622-8_6 
one of the schools said he was glad the school had not been damaged so the children will have somewhere to come back to at the start of first term: "We have families at the school who've lost absolutely everything-and a school needs to be a safe, secure place" (in Fernandez \& Lapham, 2020). Schools were also evacuated and closed during the pre-Christmas fires. School closures have significant effects on communities. Children are often left at home alone when schools are closed, and this creates significant risks for them and their families. They are also missing out on formal learning when not in school, so the fire becomes an anti-pedagogue (Rickards et al., 2019). Smoke from the bushfires also imposes on their learning as they are kept inside the school buildings rather than playing outside, and when outside they wear face masks because of the dirty air. In the coastal Victorian town of Mallacoota, 4,000 holidaymakers were stranded by bushfires cutting road access. They were then evacuated by naval ships and helicopters, often splitting families, with children going while parents remained (Millar \& McMillan, 2020) or children leading their families to evacuate (Towers et al., 2020). The traumatic effects of such experiences on children and their learning cannot be underestimated, and it makes it very clear that fire is not just "in" the curriculum, but is inside, throughout, and outside the classroom, and it acts pedagogically.

Fire has a close relationship with human evolution, but humans continue to have an ambiguous relationship with fire, as it can be a friend and fiend, and more broadly, as we will argue, unruly kin. This uneasy relationship has become even more apparent in recent times in Australia. While debate about the relationship between the bushfires and climate change continues to rage, there is also much debate about how and what fire management practices should be applied in the Australian environment. Fire is very much part of the Australian landscape and the lives of Australian people. As Indigenous fire practitioner Victor Steffensen said, "We live in a country that needs fire" (SBS News, 2016), but not the supercharged blazes of recent months, which have been fuelled by climate change and severe drought, and that, since September 2019, have torched at least 46 million acres, killed at least 34 people, destroyed more than 6,500 buildings, and resulted in the death of more than a billion animals (reptiles, birds, and mammals) (RMIT ABC Fact Check, 2020). Capital cities have also been blanketed by heavy smoke from the bushfires for days, weeks, and months on end, with potential longlasting health effects on the residents, especially children and the elderly, and an estimated 400 human deaths during the summer attributed to this. That the country (and its oceans) is getting hotter is not in doubt, except to the climate change sceptics, but even they cannot deny that we had the three hottest December days ever recorded in 2019 (Morton, 2019), and the drought continues.

In this chapter we discuss the relationship between fire and human evolution, which has led to the suggestion that recent times should be renamed the Anthropocene. We then look at how bushfires affect children and schools, and how fire is currently covered in the Australian Curriculum. This leads us 
to discussing different ways of approaching a fire pedagogy-one that is more respectful of fire as unruly kin. We acknowledge that calling fire "kin" may seem odd to some, but given that education has a role to socialise people to live in societies, and fire is now very much part of our societies, then it is not such a big leap to see fire as our unruly kin.

\section{Unruly Kin: Fire, Human Evolution, And the Pyrocene}

The discovery of fire was a pivotal moment in human evolution. Once humans had fire and could burn living and recently dead plants, they had light, had warmth, had a means of protection from other wild animals, could manage the landscape in novel ways, could make tools, and could cook their food (Glikson, 2013; Gowlett, 2016; MacDonald, 2017; Singh, 2017; Yin, 2016). Cooking also "detoxifies some foods that are poisonous when eaten raw, and it kills parasites and bacteria" (Adler, 2013). In addition, according to Andrew Glikson,

the cooking of meat and therefore enhanced consumption of proteins allowed a major physiological development into tall hairless humans. . . . The utilization of fire has thus constituted an essential anthropological development, with consequences related to bipedalism, brain size and the utilization of stone tools. (2013, pp. 89-90)

Humans also have a genetic mutation that is not found in other primates that allows certain toxins, including those found in smoke, to be metabolised safely, thus inuring humans against some adverse effects from fire, when other species were not (Yin, 2016). Such evolutionary advantages afforded to humans by their relationship to fire leads Steve Pyne (2019) to call the human alliance with fire "a veritable symbiosis." According to Pyne (2019), the story of fire defines humanity's distinctive ecological agency: "humans are a uniquely fire creature, not only the keystone species for fire but a species monopolist over its manipulation." Fire has also become socially embedded, and its influence "has reached in some way into the human psyche, expressed in religion, in ritual, in ceremony and through ubiquitous myths about fire origins" (Gowlett, 2016 , p. 7). Another aspect of human relationships with fire is its cultural consequences in relation to patriarchy: although historically some Australian Aboriginal women were involved in traditional burning practices (Steffensen, 2020), in general, "by allowing men to go out hunting while women stayed behind to cook by the fire, it spawned gender norms that still exist today" (Yin, 2016).

Fire is thus intertwined with human development, and fire can be seen as kin, in the sense used by Donna Haraway (2008, 2016). For Haraway, "kin" are those beings and bodies that we are entangled with, and who are central 
players in our processes of becoming - that is, our physical and social evolution. What she terms "companion species" (e.g., our gut bacteria, plantation crops, pets, etc.) can be our kin, but not all kin need to be living. Kin cannot be fully domesticated — and perhaps they domesticate us (Tsing, 2012)—but our relationships with kin do need keen attention and care. For Haraway, "the task is to make kin in lines of inventive connection as a practice of learning to live and die well with each other" (2016, p. 1). Complicated, messy, interwoven lives are not to be eschewed, but noticed and cultivated in ways that contribute to multispecies flourishing, and this includes the "complicated multispecies history" of fire, an agent that contributes to life, regeneration, and death (Haraway, 2016, p. 44).

In addition to the combustion of living and recently dead organic matter, there is evidence all around us that the combustion of ancient, decomposed, and compressed organic matter, i.e., fossil fuels, has also transformed human societies and systems. Indeed, our capitalist, globalised, consumer/market driven, urban systems, including transport, all stem from the burning of hydrocarbons. Fire is a process of combustion, and the products and outcomes of the combustion of fossil fuels are at the core of claims that we are now living in "the Anthropocene" (Crutzen \& Stormer, 2000), the present period of geological time dominated by human impact on the Earth's processes. The starting date for the epoch is contentious, as is the term itselfoften because of its human supremacy, and the way it hides troublesome differences between humans (including gender and cultural differences) and ignores specific humans' intimate relationships with technology and other animals (Åsberg, 2017; Gough, 2021). Indeed, Cecilia Åsberg (2017, p. 198) asserts that "nature is no longer separable from culture in this age of the Anthropocene." This has generated competing suggestions of names for the epoch, including Econocene, Capitalocene, Chthulucene, Plantationocene, and Symbiocene (Albrecht, 2016; Haraway, 2015, 2016). Given the central role of human practices of combustion in such debates, Pyne (2019) has argued that an appropriate name is the "Pyrocene": an era generated by multiple practices of combustion, and one that is characterised by increasing planetary flammability, the coming Fire Age.

The combustion of fossil fuels and its generation of the "Pyrocene" evidence our notion of fire as unruly kin. Although fossil fuels have provided great benefits to humans, their combustion has displaced-geographically but also temporally - heat energy, and this is now having unintended and increasingly unmanageable consequences, including climate change and more frequent and intense bushfires. Over Australia's Black Summer, firefighters found themselves in conditions with fires that could not be "fought," or even "contained," until heavy rains came. Who we are now is intimately entangled with our fiery histories, and who we will become is unavoidably tied to how the planet and our local ecologies burn in response. A keener attention to our past, present, and possible relations with fire, and acknowledgement of fire as unruly kin, is needed if we are to attempt the massive infrastructural, social, 
political, and economic transformations needed to avert widescale climate collapse. Yet colonial-industrial fire practices tend to aver such attunement and reflection. Thus, for a "pyro-pedagogy" (Reid, 2019, p. 771) responsive to the conditions we find ourselves in, we first turn to Indigenous fire stewardship, acknowledging that we are all white settlers and do not wish to appropriate Indigenous knowledge but rather let it be heard through drawing on Indigenous voices and sources.

\section{INDIGENOUS FIRE STEWARDSHIP}

As defined by Lake and Christianson, Indigenous fire stewardship is

the use of fire by various Indigenous, Aboriginal, and tribal peoples to: (1) modify fire regimes, adapting and responding to climate and local environmental conditions to promote desired landscapes, habitats, and species; and (2) to increase the abundance of favored resources to sustain knowledge systems, ceremonial, and subsistence practices, economies, and livelihoods. $(2019$, p. 1)

Amy Christianson (2015) draws a fundamental distinction between wildfire and fire resulting from the burning practices of Indigenous people. As she explains, wildfires can be from natural processes or human activities and generally occur in the summer months or at other times when vegetation is dry and conducive to burning out of control. In contrast, Indigenous burning is highly controlled and generally takes place during low-risk conditions: decisions about where and when to burn are guided by a deep understanding of climatic cycles, ignition sources, fire behaviour, and landscape factors, such as how the topography and vegetation/fuels contributed to the natural fire regime and associated landscape fire effects (Huffman, 2013; Lake \& Christianson, 2019; Steffensen, 2020). This knowledge, developed through multigenerational observations of fire-prone ecosystems, and the resultant Indigenous fire adaptations and cultural fire regimes, enabled Indigenous peoples on various continents to "live with fire" (Lake \& Christianson, 2019).

In Australia, Aboriginal peoples applied fire to different ecologies, at different times, shaping their surroundings for more than 65,000 years (Neale et al., 2019; Pascoe, 2018). Bruce Pascoe (2018) cites evidence from palynologists, which suggests Aboriginal Australians began using fire as a tool as long as 120,000 years ago. Before colonisation, Indigenous fire stewardship on Country (a term commonly used to describe Aboriginal homelands, and which encompasses entangled relations between ancestors, spirits, species, and place), worked on five principles: (1) the majority of agricultural lands were burned on a rotating mosaic, which controlled intensity and allowed animals and plants to survive in refuges; (2) the time of burning depended on the type of land (e.g., soil type, dominant species of vegetation) and the condition of the bush at the time; (3) the prevailing weather was crucial to the timing of the burn; (4) neighbouring clans were advised of fire activity; and (5) the 
growing season of particular plants was avoided at all costs (Pascoe, 2018; see also Steffensen, 2020). Importantly, as Victor Steffensen (2020) describes, not every ecosystem was burned: he refers to "no-fire ecosystems" and cites wet rainforests and riverbanks as key examples. Engaging with Country in this way provided many benefits and resources, including food, water, medicine, access to key areas, fibres for basketry, and protection from dangerous bushfires, sustaining human life on the continent for millennia (Huffman, 2013; Pascoe, 2018; Russell-Smith et al., 2003; Steffensen, 2020).

The Aboriginal ontological concept of "the Dreaming" embeds fire within a metaphysical context (Eriksen \& Hankins, 2015). Aboriginal people generally do not separate synergistic relationships between fire and other aspects of the physical and metaphysical: rather, those relationships are interdependent and interconnected. The scaling of those relationships extends from the individual to the universe, and is inclusive of the feedbacks within those levels (Eriksen \& Hankins, 2015; see also Steffensen, 2020). Aboriginal fire knowledge is applied to the landscape to nurture and maintain those relationships, and the knowledge is passed from one generation to next through lore and cultural practice (Steffensen, 2020; Pascoe, 2018): "cultural fire helps prevent fire risks, rejuvenate local flora, [and] protect native animal habitat, all while restoring the kinship to the land" (Oliver Costello, cited in Higgins, 2020).

The process of colonisation severely limited Indigenous fire stewardship practices in countries around the world (Eriksen \& Hankins, 2015; Lake \& Christianson, 2019; Mistry, 2000), including Australia (Gammage, 2011; Neale, 2018; Neale et al., 2019; Pascoe, 2018; Weir et al., 2020). When the British invaded the Australian continent in 1788, colonial interests disrupted the Aboriginal use of fire through the forced removal of people from their sovereign lands and a policy of fire prohibition (Eriksen \& Hankins, 2015; Gammage, 2011; Vale, 2002). The colonial worldview was that fires were destructive to the timber supply and dangerous to communities (Pyne, 2007). Interestingly, when the colonists invaded, they found what historian Bill Gammage has referred to as "the Greatest Estate on Earth"-vast park-like environments in which large trees were carefully situated within pampered grasslands, providing sustenance and shelter to an array of grazing animals. Ironically, these landscapes, so appreciated by the colonists, were created by the very fires they feared (Turner, 1999). Kohen (cited in Pascoe, 2018, p. 165) put it best:

While Aboriginal people used fire as a tool for increasing the productivity of their environment, Europeans saw fire as a threat. Without low intensity burning, leaf litter accumulates, and crown fires can result, destroying everything in their path. European settlers feared fire, for it could destroy their houses, their crops and it could destroy them. Yet the environment that was so attractive to them was created by fire. 


\section{Fire And the Australian Curriculum}

Such nuanced understandings of fire as part and parcel of life on this flammable continent, and something to be embraced, celebrated, and respected, is largely absent from Australian culture, which aligns with broader Western cultural relationships with fire. According to Pyne (2019),

Fire disappeared as an integral subject about the time we hid fire into Franklin stoves and steam engines ... It lost standing as a topic in its own right. As with the fires of today, its use in history has been to illustrate other themes, not to track a narrative of its own.

An analysis of the Australian Curriculum (ACARA, 2019) supports this observation. Combustion is not covered as a topic in Science (or anywhere else) until Year 9. Here the Content Description statement is "chemical reactions, including combustion and the reactions of acids, are important in both nonliving and living systems and involve energy transfer," and the two Content Elaborations are "recognising the role of oxygen in combustion reactions and comparing combustion with other oxidation reactions" and "describing how the products of combustion reactions affect the environment." Fire is also not discussed in Science until Year 9, and here it is only a "such as" in an Elaboration. The Content Description statement is: "Ecosystems consist of communities of interdependent organisms and abiotic components of the environment; matter and energy flow through these systems" and the associated Elaboration is "investigating how ecosystems change as a result of events such as bushfires, drought and flooding" (ACARA, 2019).

The most comprehensive location for the study of bushfires in the Australian Curriculum is in Year 5 Geography. Here the Content Description statement is: "The impact of bushfires or floods on environments and communities, and how people can respond," and this is elaborated as.

- mapping and explaining the location, frequency and severity of bushfires or flooding in Australia

- explaining the impacts of fire on Australian vegetation and the significance of fire damage on communities

- researching how the application of principles of prevention, mitigation and preparedness minimises the harmful effects of bushfires or flooding.

Climate change does not fare much better in the Science curriculum. It only appears in three Elaborations in Year 9 Science. The Content Description statement says, "Scientific understanding, including models and theories, is contestable and is refined over time through a process of review by the scientific community," and in the Elaboration there is "considering the role of science in identifying and explaining the causes of climate change." The Content Description "advances in scientific understanding often rely 
on technological advances and are often linked to scientific discoveries" includes "considering how computer modelling has improved knowledge and predictability of phenomena such as climate change and atmospheric pollution," and the Content Description "people can use scientific knowledge to evaluate whether they accept claims, explanations or predictions and advances in science can affect people's lives including generating new career opportunities" includes the Elaboration "considering the scientific knowledge used in discussions relating to climate change."

These silences around fire and climate change in the written curriculum are very concerning, as teachers increasingly only teach what is going to be assessed (Popham, 2001) and are less likely to teach that which is not explicitly written into the curriculum (Earp, 2019). This affects what is then taught and learned. The implementation and effectiveness of this curriculum has not been reviewed at a state, territory, or national level since it was developed. Given the curriculum isn't always taught in the same way as it is written, we should not assume bushfire education is being delivered as intended, or that it is being delivered at all.

One problem with the Australian Curriculum content statements is that they are relatively abstract and detached from children's lived experiences (Towers et al., 2020). Towers (2015) interviewed Australian children aged 812 to find out their knowledge of bushfire emergency responses and found many misconceptions about bushfire safety, which often came from a lack of knowledge about bushfire behaviour. For example, children often assume bushfires only travel through direct flame contact and think a nonflammable physical barrier (such as a river, a road, or a brick wall) will prevent a bushfire from reaching their property. But burning embers can travel many kilometres ahead of the fire front, and ember attack is a major cause of home ignitions. Such misconceptions are best addressed by making bushfire education more relevant to their own lives. Children need to explore and understand vulnerability to bushfire in their own communities as well as their capacity for reducing risk.

Bushfire education in schools is more effective when taught across the curriculum, rather than as isolated topics. One example is the bushfire education programme at Victoria's Strathewen Primary School for students in grades five and six. It incorporates science, art, civics and citizenship, design, English, and geography. An evaluation of this programme (Towers et al., 2018) showed it increased children's knowledge of local bushfire risks and the actions people can take to manage them. It also helped increase children's confidence for sharing their knowledge with others, gave them a sense of empowerment, and reduced bushfire-related anxieties. The programme's benefits extended to families, including increased bushfire planning at home with more participation from children in the process.

Traditionally, school-based disaster risk reduction and resilience education (DRRRE), such as bushfire education, has tended to adopt a transmission model of education, where a specific body of knowledge is transferred from 
adult to child. In this model, children are positioned as passive receivers of information as opposed to critical thinkers and problem solvers. This model also tends to be information driven rather than action oriented. Even when children are encouraged to take action, adults often prescribe the action, and there are limited opportunities for children to creatively address other issues that might concern them and for them to feel empowered to act at critical moments. What is needed is a more child-centred approach that is more holistic, place-based, and participatory. Such approaches not only provide children with essential knowledge and skills, but also empower them to actively participate in disaster risk reduction and resilience-building activities. We also need a pedagogy that embraces becoming-with fire: one where the boundaries between the students and fire "move, blur, dissolve and/or are (re)established due to their on-going intra-action" (Nakagawa et al., 2020, p. 11; see also Verlie, 2018, for an example of becoming-with climate, and with fossil fuels).

\section{Pyro-Pedagogies of Becoming-With}

"Our house is on fire" proclaimed Greta Thunberg (2019), and following her, thousands of young people around the world protested governmental inaction on climate change. These words reverberated ever louder as children and young people around Australia mobilised in public spaces with atmospheres thick with the airborne remains of native forests throughout the southern summer of 2019/2020 (Wahlquist, 2019; Regan \& Yeung, 2020). Shouting from behind their P2 masks, we saw young people standing up for their futures, and becoming activists in the process. Exploring young people's lived experiences of bushfire within a colonial, carbon-intensive economy, pushes us to consider potentials for alternative pyro-pedagogies. The Black Summer demonstrates that fire operates pedagogically well beyond the confines of the classroom, and exerts agency exceeding the bounds of curriculum statements that dictate how to teach "about" fire. In multiple, intersecting, and reverberating ways, fire affects who we are and can be as humans. Our relationships with fire are changing, meaning that we are changing at a fundamental level of who we are, how we understand what it is to be human, and how we can live in this hot, dry, colonised country. Thus, we are calling for pyro-pedagogies founded on a notion of becoming-with fire, our unruly kin.

Reconsidering "what" "where" and "when" fire is, is a preliminary move towards this. As noted previously with respect to some children's recent lived experience of bushfire, fire is not just "in" the curriculum but is inside, throughout, and outside the classroom. Indeed, combustion co-composes what the classroom is: what it is made of, where it is, whether and how it is heated, how students and staff get to school, what they eat, and how flammable and at risk it is, etc. And classrooms co-compose fire, reciprocally: the school system more broadly is embedded in fossil fuel economies, and it positions children as future workers in capitalist systems. The material economies that build classrooms literally contribute to emissions which fuel 
fires. Classrooms and fire are much more closely and intimately related than we might typically think.

We are also advocating for understanding fire not just as something to be learned about, but as a pedagogue that operates through its role as unruly kin. Across Australia's Black Summer, children were kept home, sent home and evacuated from school, kept indoors, sent to hospitals, evacuated from holidays, evacuated with their families, participants in recovery efforts, and more. For young people who led their families to safety (Towers et al., 2020) this was surely a life-changing moment, and their sense of self will be affected in profound ways, even if we cannot anticipate that or even trace it with accuracy. That these experiences occur outside of classrooms does not mean they are not pedagogical or curricular. We don't know exactly what students are learning, or who or what they are becoming through these processes. The point is that fire is a pedagogue that exceeds the capacities of teachers, parents, and humans more broadly - it is unruly, and it changes us in significant, species- and society-changing ways. Further, even within "climate controlled" classrooms, and when mediated through imagery and narrative, fire acts pedagogically (Verlie, 2019a), especially in affective ways. All of this considered, we know that after this Black Summer things will not be the same: Australian culture will not be the same, and summer itself will not be the same. For example, people have gone from counting down the days until summer holidays start, to counting down the days until summer is over, indicating a significant affective change in our relationships with weather, seasonality, climate change, and our forests.

Part of fire's pedagogical capacities is its ability to shape who and how we become. Our focus on "kin" and "becoming" emphasises that human relationships with the non-human world are dynamic and open to the agency of the nonhuman world. Such a pedagogy does not provide clear-cut, practical suggestions of how and what to teach, but emphasises the need to continually be attuning to the agency of the world and how it interacts with and affects students' whole lives (Verlie, 2017; Nakagawa et al., 2020). However, we can become-with fire in different ways, and educators can play a role by "sparking" such changes and directing pyro-pedagogies in certain ways. For example, in traditional DRRRE, children might become hazard managers, replete with the reductive, top down, resource management approach to trying to keep nature in its place. Alternatively, they could become cultural burners and stewards of fire, if supported to learn from and engage with Aboriginal culture and ecological practice-such as through Marcia Langton's (n.d.) Resources in Aboriginal and Torres Strait Islander Histories and Cultures for Teachers. An Aboriginalled pyro-pedagogy could be our moment for rejecting human exceptionalism, through attending to fire's unruly, massive, and terrifying but also beneficial and healing qualities.

A pyro-pedagogy of becoming-with fire would also be situated and placebased. As CSIRO bushfire expert Justin Leonard (in SBS News, 2016) said, “there's a way to live in every part of the landscape and it's this integrated way 
of understanding what, what fire is in that location, how to find the balance and manage the bush in the right way, and that easily unlocks how you build and live and behave and understand." Rejecting colonisers' logics that there is one right way to live in all places, and focusing on how particular combustive ecologies intersect with particular cultures and experiences will be fundamental to cultivating education that is relevant to children's whole lives. A situated and relevant pyro-pedagogy would also contribute to the transdisciplinary and participatory modes of education that Teresa Lloro-Bidart (2015) argues are necessary in the Anthropocene. This pedagogy also needs to adopt a wholeschool approach, in line with Steffensen's (in SBS News, 2016) suggestion that we need to involve "communities in understanding fire. Not in its vicious form or its threatening form but understanding fire and its nurturing and... how beautiful it really is."

Briony Towers' (2019) research on bushfire education offers important insights for such pyro-pedagogies. For children to develop a coherent understanding of bushfire risk that is sufficient for identifying problems and solutions in their own local context, Towers argues that a holistic learning framework that incorporates the environmental and social dimensions is needed. "This requires teaching and learning activities that systematically build children's knowledge and awareness of the various dimensions of risk-the physical hazard, exposure, vulnerability and capacities - and how those dimensions interact to cause hazard impacts and disasters" (2019, p. 72). Towers also argues that there needs to be a.

place-based pedagogy of bushfire risk, [where] the surrounding socioenvironmental context serves as the learning ecosystem: abstracted environments are substituted with local landscapes; textbooks and worksheets are replaced by local experts and experiential activities in the field; and generic information about bushfire risk is augmented by local knowledge, data and predictions. (2019, p. 73)

Such an approach, that situates children in their specific worlds and sees them as active subjects who interact with and become-with fire, demonstrates that understanding fire as unruly kin that our children are unavoidably entangled with can generate pedagogies responsive to the conditions of the Pyrocene. Through acknowledging and teaching about fire's unruly capacities, we can steer students towards more ecologically attuned and responsive and resilient ways of being.

\section{CONCLUSION}

Robert Glasser $(2019$, p. 4) was quite prescient when he wrote in early 2019, "This emerging Era of Disasters will increasingly stretch emergency services, undermine community resilience and escalate economic costs and losses of life." What the bushfires of Australia's 2019/2020 Black Summer have shown us is that we need a different relationship with fire in the environment, one 
that recognises fire as our unruly kin and which foregrounds the agency of human and more-than-human materiality (i.e., "nature") and their entanglement. We see a pyro-pedagogy of becoming-with fire as building on each of our previous writings-Annette Gough's (2019) on more-than-human scientific inquiry in education, Blanche Verlie's (2018) on becoming-with climate change, and Briony Towers (2019) on child-centred DRRRE-and more. In doing this we have much to learn from Victor Steffensen and other First Nations peoples. We also hear young people's refrain, our house is on fire, calling ever more loudly for education to recognise that climate change is radically reconfiguring the fundamental conditions of children's lives today and in the future. Thus, we believe that thinking much more broadly about humanity's entanglement with fire-the histories, futures, geographies, and affective ecologies of various kinds of combustion-is necessary if we are to enable our young people to learn to live with climate change (Verlie, 2019b). This is very different from the current abstract, teacher-centred approaches to bushfire and climate change education in the Australian Curriculum, but one that is sorely needed.

Acknowledgements We acknowledge that this chapter was written by Annette and Briony on the land of the Wurundjeri people of the Kulin nation in which Melbourne now is located, and by Blanche on the land of the Gadigal people of the Eora nation in which Sydney is now located. We pay our respects to the Elders both past and present, and to those emerging.

\section{REFERENCES}

Adler, J. (2013, June). Why fire makes us human. Smithsonian Magazine. https:// www.smithsonianmag.com/science-nature/why-fire-makes-us-human-72989884/.

Albrecht, G. A. (2016). Exiting the Anthropocene and entering the Symbiocene. Minding Nature, 9(2). https://www.humansandnature.org/filebin/pdf/minding_n ature/may_2016/Albrecht_May2016.pdf.

Åsberg, C. (2017). Feminist posthumanities in the Anthropocene: Forays into the postnatural. Journal of Posthuman Studies, 1(2), 185-204. https://doi.org/10. 5325/jpoststud.1.2.0185.

Australian Curriculum and Assessment Authority (ACARA). (2019). Australian Curriculum. http://www.australiancurriculum.gov.au.

Bonyhady, N. (2020, January 21). Prime minister says hazard reduction burns as important as emissions. The Sydney Morning Herald. https://www.smh.com.au/ politics/federal/prime-minister-says-hazard-reduction-burns-are-climate-action-202 00121-p53tha.html.

Cave, D. (2020, February 15). The end of Australia as we know it. The New York Times. https://www.nytimes.com/2020/02/15/world/australia/fires-climate-cha nge.html.

Christianson, A. (2015). Social science research on indigenous wildfire management in the 21 st century and future research needs. International Journal of Wildland Fire, 24, 190-200. 
Chrysanthos, N. (2020, January 17). NSW to spend \$20 million on bushfire recovery for 178 schools. The Sydney Morning Herald. https://www.smh.com.au/national/ nsw/nsw-to-spend-20-million-on-bushfire-recovery-for-178-schools-20200116-p53 s04.html.

Crutzen, P. J., \& Stoermer, E. F. (2000). The “Anthropocene.” Global Change Newsletter, 41, 17-18.

Earp, J. (2019, November 13). Education reform: Curriculum content and deep learning. Teacher Magazine. https://www.teachermagazine.com.au/articles/educat ion-reform-curriculum-content-and-deep-learning.

Eriksen, C., \& Hankins, D. (2015). Colonisation and fire: Gendered dimensions of indigenous fire knowledge retention and revival. In A. Coles, L. Gray, \& J. Momsen (Eds.), The Routledge handbook of gender and development (pp. 129-137). Routledge.

Faa, M. (2019, November 14). Indigenous leaders say Australia's bushfire crisis shows approach to land management failing. $A B C$ News. https://www.abc.net.au/news/ 2019-11-14/traditional-owners-predicted-bushfire-disaster/11700320.

Fernandez, T., \& Lapham, J. (2020, January 16). Back to school-NSW Education Minister says 140 bushfire-hit sites will be safe for students. $A B C$ News. https://www.abc.net.au/news/2020-01-16/nsw-fire-affected-schoolswill-be-safe-for-returning-students/11870494.

Flanagan, R. (2020, January 25$)$. How does a nation adapt to its own murder? The New York Times. https://www.nytimes.com/2020/01/25/opinion/sunday/austra lia-fires-climate-change.html.

Gammage, B. (2011). The biggest estate on Earth: How aborigines made Australia. Allen \& Unwin.

Glasser, R. (2019, March). Preparing for the era of disasters. Special report. Australian Strategic Policy Institute.

Glikson, A. (2013). Fire and human evolution: The deep-time blueprints of the Anthropocene. Anthropocene, 3, 89-92. https://doi.org/10.1016/j.ancene.2014. 02.002 .

Gough, A. (2019). Symbiopolitics, sustainability, and science studies: How to engage with alien oceans. Cultural Studies $\leftrightarrow$ Critical Methodologies. https://doi.org/10. $1177 / 1532708619883314$.

Gough, A. (2021, February 23). Education and the anthropocene. In C. Mayo (Ed.), Oxford encyclopedia of gender and sexuality in education. Oxford University Press. https://doi.org/10.1093/acrefore/9780190264093.013.1391.

Gowlett, J. A. J. (2016). The discovery of fire by humans: A long and convoluted process. Philosophical Transactions Royal Society B, 371, 20150164. https://doi.org/ $10.1098 /$ rstb.2015.0164.

Haraway, D. (2008). When species meet. University of Minnesota Press.

Haraway, D. (2015). Anthropocene, Capitalocene, Plantationocene, Chthulucene: Making kin. Environmental Humanities, 6, 159-165. https://doi.org/10.1215/ 22011919-361593.

Haraway, D. (2016). Staying with the trouble: Making kin in the Chthulucene. Duke University Press.

Higgins, I. (2020, February 9). Indigenous fire practices have been used to quell bushfires for thousands of years, experts say. $A B C$ News. https://www.abc.net.au/ news/2020-01-09/indigenous-cultural-fire-burning-method-has-benefits-expertssay/11853096. 
Huffman, M. (2013). The many elements of traditional fire knowledge: Synthesis, classification, and aids to cross-cultural problem solving in fire-dependent systems around the world. Ecology and Society, 18(4). https://doi.org/10.5751/ES-05843180403.

Keneally, T. (2020, February 1). Thomas Keneally: 'These fires have changed us.' The Guardian. https://www.theguardian.com/australia-news/2020/feb/01/ thomas-keneally-these-fires-have-changed-us? $\mathrm{CMP}=$ share_btn_link.

Lake, F., \& Christianson, A. (2019). Indigenous fire stewardship. In S. L. Manzello (Ed.), Encyclopedia of wildfires and wildland-urban interface (WUI) fires. https:// doi.org/10.1007/978-3-319-51727-8_225-1.

Langton, M. (n.d.). Resources in Aboriginal and Torres Strait Islander histories and cultures for teachers. https://indigenousknowledge.research.unimelb.edu.au/.

Lippmann, T., Abram, N., Sharples, J., Clarke, H., Sen Gupta, A., Meissner, K., Boer, M., Henley, B., Rohling, E., Tapper, N., Alexander, L., Sawyer, R., Mcgowan, H., Yebra, M., Russell-Smith, J., Murphy, B., Grierson, P., Nolan, R., Penman, T., ... Bell, T. (2020, February 3). There is no strong, resilient Australia without deep cuts to greenhouse gas emissions: An open letter on the scientific basis for the links between climate change and bushfires in Australia. https://australianbushfiresandcl imatechange.com/.

Lloro-Bidart, T. (2015). A political ecology of education in/for the Anthropocene. Environment and Society: Advances in Research, 6, 128-148. https://doi.org/10. 3167 /ares.2015.060108.

MacDonald, K. (2017). The use of fire and human distribution. Temperature, 4(2), 153-165.

Marshall, K. (2020, January 25). The 'forever fires' and Australia's new reality. The Age Good Weekend. https://www.theage.com.au/national/the-forever-fires-and-aus tralia-s-new-reality-20200122-p53tk0.html.

Millar, R., \& McMillan, A. (2020, January 5). Victoria bushfires: Exhausted families farewell fire-racked Mallacoota. The Age. https://www.theage.com.au/national/ victoria/victoria-bushfires-exhausted-families-farewell-fire-racked-mallacoota-202 $00105-\mathrm{p} 53 \mathrm{pld}$.html.

Mistry, J. (2000). World savannas: Ecology and human use. Prentice-Hall.

Morton, A. (2019, December 21). Climate of chaos: The suffocating firestorm engulfing Australia. The Guardian. https://www.theguardian.com/australia-news/ $2019 / \mathrm{dec} / 20 /$ climate-of-chaos-the-suffocating-firestorm-engulfing-australia.

Nakagawa, Y., Verlie, B., \& Kim, M. (2020). Collectively engaging with theory in environmental education research. Australian Journal of Environmental Education. https://doi.org/10.1017/aee.2020.6.

Neale, T. (2018). Digging for fire: Finding control on the Australian continent. Journal of Contemporary Archaeology, 5(1), 79-90. https://doi.org/10.1558/jca. 33208.

Neale, T., Carter, R., Nelson, T., \& Bourke, M. (2019). Walking together: A decolonising experiment in bushfire management on Dja Dja Warrung country. Cultural Geographies, 26(3), 341-359.

Pascoe, B. (2018). Dark emu: Aboriginal Australia and the birth of agriculture. Magabala Books.

Popham, W. J. (2001). Teaching to the test. Educational Leadership, 58(6), 16-20.

Pyne, S. J. (2007). Awful splendour: A fire history of Canada. UBC Press. 
Pyne, S. (2019, August 25). Winter isn't coming. Prepare for the Pyrocene. History News Network. https://historynewsnetwork.org/article/172842.

Regan, H., \& Yeung, J. (2020, January 10). Tens of thousands protest Australian PM's climate policies amid bushfire crisis. CNN. https://edition.cnn.com/2020/ 01/10/australia/australia-fires-climate-protest-morrison-intl-hnk/index.html.

Reid, A. (2019). Climate change education and research: Possibilities and potentials versus problems and perils? Environmental Education Research, 25(6), 767-790.

Rickards, L., Verlie, B., Towers, B., \& Lay, B. (2019, November 19). Climate is disrupting children's education. Eureka Street. https://www.eurekastreet.com.au/ article/climate-is-disrupting-children-s-education.

RMIT ABC Fact Check. (2020, February 4). Have more than a billion animals perished nationwide this bushfire season? Here are the facts. https://www.abc. net.au/news/2020-01-31/fact-check-have-bushfires-killed-more-than-a-billion-ani mals/11912538.

Russell-Smith, J., Yates C., Edwards A., Allan, G., Cook, G., Cooke, P., Craig, R., Heath, B., \& Smith, R. (2003). Contemporary fire regimes of northern Australia, 1997-2001: Change since Aboriginal occupancy, challenges for sustainable management. International Journal of Wildland Fire, 12(4), 283-297.

SBS News. (2016, February 16). Insight S2016 Ep2-Line of Fire. https://www.sbs. com.au/programs/video/614446147894/Insight-S2016-Ep2-Line-of-Fire.

Scolaro, N. (2018, August 20). Victor Steffensen listens to the land. Dumbo Feather. https://www.dumbofeather.com/conversations/victor-steffensenlistens-to-the-land/.

Singh, P. (2017, April 24). Importance of discovery in human brain development. Medium. https://medium.com/@Prakhar_Singh/importance-of-fire-forhuman-brain-development-24b78638fdbc.

Steffensen, V. (2020). Fire country: How indigenous fire management could belp save Australia. Explore Australia.

Thunberg, G. (2019, January 29). 'Our house is on fire': Greta Thunberg, 16, urges leaders to act on climate. The Guardian. https://www.theguardian.com/enviro nment/2019/jan/25/our-house-is-on-fire-greta-thunbergl6-urges-leaders-to-acton-climate.

Towers, B. (2015). Children's knowledge of bushfire emergency response. International Journal of Wildland Fire, 24(2), 179-189. https://doi.org/10.1071/WF1 3153.

Towers, B. (2019). School-based bushfire education: Advancing teaching and learning for risk reduction and resilience. Australian Journal of Emergency Management, Monograph No. 5, 71-74.

Towers, B., Gough, A., \& Verlie, B. (2020, January 22). Bushfire education is too abstract. We need to get children into the real world. The Conversation. https://theconversation.com/bushfire-education-is-too-abstract-weneed-to-get-children-into-the-real-world-129789.

Towers B., Perillo, S., \& Ronan, K. (2018). Evaluation of survive and thrive: Final report to the Country Fire Authority. Bushfire and Natural Hazards CRC.

Tsing, A. (2012). Unruly edges: Mushrooms as companion species. Environmental Humanities, 1, 141-154.

Turner, N. J. (1999). Time to burn. In R. Boyd (Ed.), Indians, fire and the land in the Pacific Northwest (pp. 185-218). Oregon State University Press.

Vale, T. (Ed.). (2002). Fire, native peoples, and the natural landscape. Island Press. 
Verlie, B. (2017). Rethinking climate education: Climate as entanglement. Educational Studies, 53(6), 560-572. https://doi.org/10.1080/00131946.2017.1357555.

Verlie, B. (2018). From action to intra-action? Agency, identity and "goals" in a relational approach to climate change education. Environmental Education Research, 1-15. https://doi.org/10.1080/13504622.2018.1497147.

Verlie, B. (2019a). "Climatic-affective atmospheres": A conceptual tool for affective scholarship in a changing climate. Emotion, Space and Society, 33, 100623. https:// doi.org/10.1016/j.emospa.2019.100623.

Verlie, B. (2019b). Bearing worlds: Learning to live-with climate change. Environmental Education Research, 25(5), 751-766.

Wahlquist, C. (2019, November 29). Climate change strike: Thousands of school students protest over bushfires. The Guardian. https://www.theguardian.com/ world $/ 2019 / \mathrm{nov} / 29 /$ climate-change-strike-thousands-of-school-students-protestover-bushfires.

Weir, J., Sutton, S., \& Catt, G. (2020). The theory/practice of disaster justice: Learning from indigenous peoples' fire management. In A. Lukasiewicz \& C. Baldwin (Eds.), Natural hazards and disaster justice: Challenges for Australia and its neighbours (pp. 299-317). Palgrave Macmillan.

Williamson, B., Weir, J., \& Cavanagh, V. (2020, January 10). Strength from perpetual grief: How Aboriginal people experience the bushfire crisis. The Conversation. https://theconversation.com/strength-from-perpetual-grief-how-aboriginalpeople-experience-the-bushfire-crisis- 129448 .

Yin, S. (2016, August 5). Smoke, fire and human evolution. The New York Times. https://www.nytimes.com/2016/08/09/science/fire-smoke-evolution-tub erculosis.html.

Open Access This chapter is licensed under the terms of the Creative Commons Attribution 4.0 International License (http://creativecommons.org/licenses/by/4.0/), which permits use, sharing, adaptation, distribution and reproduction in any medium or format, as long as you give appropriate credit to the original author(s) and the source, provide a link to the Creative Commons license and indicate if changes were made.

The images or other third party material in this chapter are included in the chapter's Creative Commons license, unless indicated otherwise in a credit line to the material. If material is not included in the chapter's Creative Commons license and your intended use is not permitted by statutory regulation or exceeds the permitted use, you will need to obtain permission directly from the copyright holder. 